Bojan R. Babić

Professor

University of Belgrade

Faculty of Mechanical Engineering

\section{Aleksandar Grbović}

Assistant Professor University of Belgrade

Faculty of Mechanical Engineering

\section{Zoran Stefanović}

Professor

University of Belgrade

Faculty of Mechanical Engineering
To produce a new component there are a trial and error stage to obtain a part without defects, which strongly depends on operator's experience. At this stage, the experience of designer and manufacturers should give an important aid to reduce trials to realize the minimization of response time and cost with maximization of the product equality. Rubber pad forming highly improves the formability of the blank because the contact surfaces between the rigid die and the rubber pad is flexible. This method enables to produce sheet metal components with complex contour by relatively low cost because only one rigid die is required. However, in aerospace field, parts are produced in small sheet metal bending and small number of components. It means that it is not worthy for large investments in tools and process design. For these reasons, it is necessary to use FE simulation of manufacturing process during the conceptual design.

Keywords: Rubber pad forming, Sheet metal forming, FE simulation, Optimization.

\section{INTRODUCTION}

There are other alternatives to form complex shape besides conventional forming processes such as deep drawing, bending, stretching, stamping and blanking. Among sheet forming rubber pad forming, also known as flexible die forming, uses a rubber diaphragm as one half of tool. This method requires only one solid tool half, which is usually, punch. The rubber pad is used to distribute equal pressure on all work piece surface as it is pressed around the form block. Rubber pad forming is designed for the use of fabricating parts with relatively complex shape. The form block height is usually less than $100 \mathrm{~mm}$, when production rates are relatively high with cycle times averaging $1 \mathrm{~min}$ or less [1].

In the aircraft industry most of the sheet parts, such as ribs, frames, doors and windows are fabricated using the rubber-pad forming processes. The main advantages of this forming process compared to conventional one are that: e.g. the forming equipment is simple and the quality of its products is high and using it instead of the conventional one. Because just one rigid die needs to be accurately manufactured, the time and cost can be greatly reduced, and the rubber pad and rigid die do not need to be assembled precisely. Also no die clearance or alignment checks are needed. Furthermore the same flexible pad can be used to form several different work piece shapes, because the rubber-pad has the ability to return to its original shape. The thinning of the work metal, which occurs in conventional deep drawing, is considerably reduced. One more advantage, lubrication is usually not needed with this process and good surface finish can be achieved. The set-up time can be

Received: May 2013, Accepted: Dcember 2013

Correspondence to: Prof. Dr. Bojan Babić

Faculty of Mechanical Engineering,

Kraljice Marije 16, 11120 Belgrade 35, Serbia

E-mail: bbabic@mas.bg.ac.rs

doi:10.5937/fmet1401067B

(C) Faculty of Mechanical Engineering, Belgrade. All rights reserved considerably reduced in this kind of process, because there are no die clearance or alignment checks that need to be made. The rubber-pad forming processes have certain disadvantages. However the rubber pad has a limited life time that strongly depends on the severity of the forming in combined with the pressure level. The lack of sufficient forming pressure results in parts with less sharpness or with wrinkle, which leads to reworking the part to correct the shape and dimensions with low production rate. Therefore it is suitable mostly for small series (typical of aircraft industry) $[1,2,7]$.

Fortunately there are a number of research development articles written on the use of rubber pad forming. For instance Antonio [2] investigated the capability to produce shallow formed parts with a reduced metal thinning. E. Akdemir [4] presented the significant numerical simulation associated with flexible forming process by 3D finite element simulation. Their investigation showed the influence of the rubber pad hardness and the stress distribution in the forming of different blank material types. They also investigated contact friction, die design crucial parameters that required adjustment before actual operation. Ramezani [6] presented an experimental study for the rubber-pad forming process to stamp aluminium blank and investigated the effect of the rubber type and stamping velocity on the process. Finite element simulation was used to analyse the process and compared with experimental measurements to validate the finite element model. Sala [7] optimized the Guerin rubber pad forming process of an aluminium alloy fuselage frame, which belonging to the AerMacchi MB-339 trainer and used the own finite element code. Several effects depending on stamping velocity, geometry, heat treatment of the sheet metal and rubber-pad parameters have been investigated. S. Thiruvarudchelvan [8] presented several techniques that have been introduced and developed the role of urethane in the design of 
metal forming tool such as sheet metal ashtray, plates, a tube bulging technique, a novel blank holding technique for deep drawing of cups of different shapes and redrawing of cups. Battikha [9] presented the capability of the rubber pad forming process and optimized the process parameters to find out a product without defect. Yaniong Liu and Lin Hua [10] reported that the finite element simulation and experiment methods were investigated the concave and convex rubber-pad forming process. The forming load, thickness variation of formed plate and variations in the channel width to rib width ratio were also performed. Fabrizio and Loreddana [11] presented the flexible forming of thin sheet from aluminium alloy using different flexible die geometries and materials. They have investigated the forming force during the forming process for different dies and evaluated together with the part spring back. These investigations showed the sufficient agreement between numerical and experimental data. Ramezani et al. [12] presented a theoretical model for static and kinematic friction in rubber pad forming process. They applied these models to finite element simulation of an axisymmetric rubber pad forming operation. Experiments of rubber pad forming were carried out using flexible punch.

The result of finite element simulation using the new models illustrated better agreement between experiments and numerical simulation. Lee et al. [13] presented deformation characteristics of an extruded rectangular aluminium tube in rubber pad bending and process parameters such as material property of rubber and roller diameters. The finite element analyses were performed. Based on the FE analyses and parametric, a critical value of sectional deformation and minimum formable radius of curvature while maintaining suitable section bending rigidly were determined. Linfapeng [14] presented the micro/meso sheet soft punch stamping process to fabricate the micro channel via numerical simulation and experiments. They have analysed the significant parameters with this process, such as hardness of soft punch and lubrication condition, and the numerical results have validated by experimentally. Yanxiong Liu and Lin Hua [15] have investigated the finite element to analysis the rubber pad forming process and the main parameters of this process such as rubber hardness and geometric dimension of the rigid die of metallic bipolar plate and verification these results with experiments.

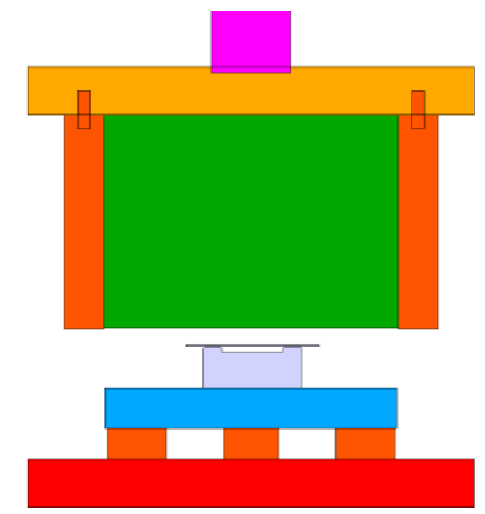

Figure 1. Schematic of rubber pad forming
These finite element models of rubber pad forming process are studied to investigate the effect of tool geometry for supporting ribs of an aircraft tail, to optimize the tool geometry and to find out the right design of tool for a defect free product. Non-linear FE analysis (using the ANSYS Workbench) was conducted in order to analyse stress distribution, strain distribution, forming load and deformation mechanics during the rubber pad forming process. This analysis was carried out on a commercially available finite element package with appropriate nonlinear material and friction model.

\section{FINITE ELEMENT MODELING}

The deformation characteristic of support rib with lightening hole using the rubber pad forming process is conducted, Figure 1. During the process the blank is placed between the die and rubber pad, which is later held in a container to enclosing the flexible punch, and the die is held on the hydraulic testing machine. At this stage, the rubber bad (flexible punch) moves down to form the blank. As a flexible punch moves down, the rubber deforms elastically and offers a counter pressure, making the rubber pad and blank flows into cavity of the die. This process can be divided into three steps: first step is self-deformation of rubber, second step is blank draws to the surface of die and produces outer bending, and the third is rubber pad pushing the blank in to the die cavity. The Polyurethane rubber with Shore A hardness of 70 (HD70) was used as a rubber pad to stamping the aluminum blank which has thickness of $0.6 \mathrm{~mm}$.
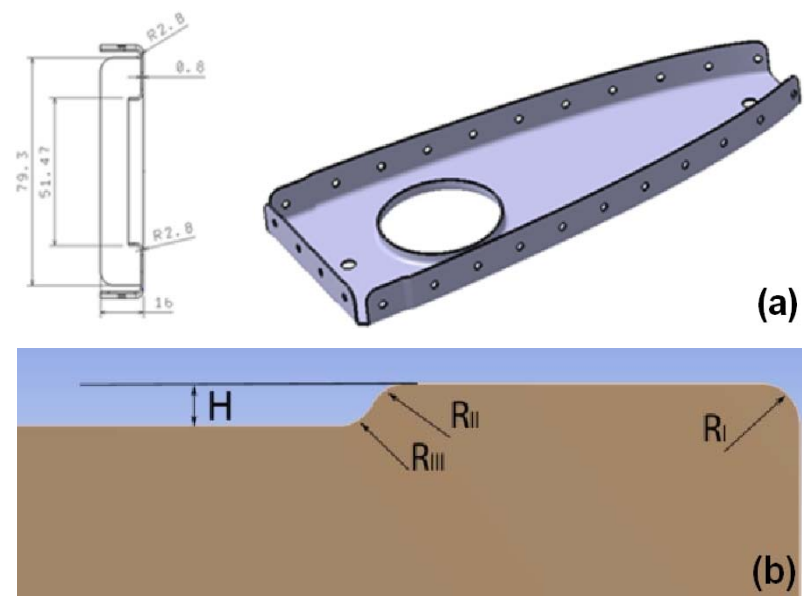

Figure 2. (a) Geometrical model of the rib with lightening hole, (b) Geometry parameters varied in FE simulations of rubber pad forming

In order to reduce the processing time and to improve the precision of calculations which lead to the right design of tool dimensions, $2 \mathrm{D}$ axisymmetric $\mathrm{FE}$ models were created for different die dimensions (parameters) Figure 2 (a) illustrates the geometrical model of the rib with lightening hole and Geometry parameters varied in FE simulations of rubber pad forming (Figure 2 (b)) . The models in FE analysis included only three parts: a rigid die, a blank and a rubber pad (flexible punch). To simplify the model, the container of the rubber pad was not considered and constrains were applied on the rubber pad instead of container as shown in Figure 3. 


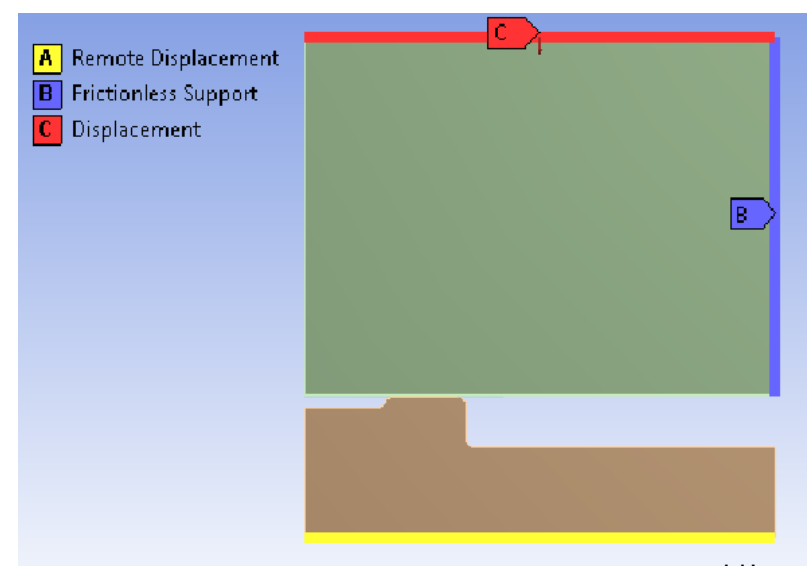

Figure 3. Constraints as applied in symmetry FE model of rib with lighten hole

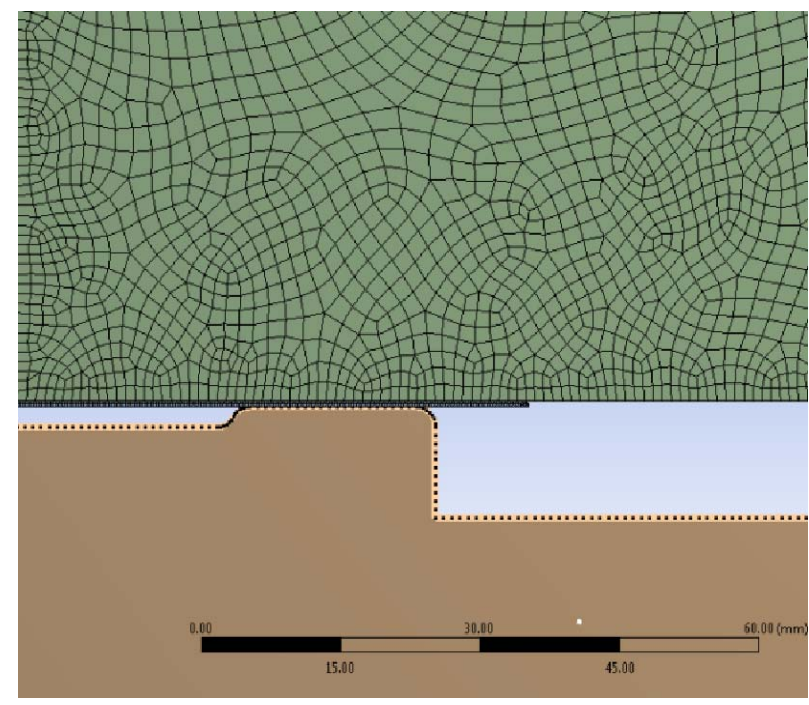

Figure 4 Rigid punch, sheet metal and rubber pad models

However, in these models die was modeled as a rigid body, so the mesh for this element was not generated (Figure 4). Multilinear isotropic hardening properties of 2024-T3 aluminum alloy were assigned to the blank in order to successfully simulate large plastic strain of the blank. These properties were determined from stress-strain curve obtained in the tensile test (Figure 5). For this material the elastic module (E) is $71 \mathrm{GPa}$ and Poisson ratio (v) is 0.334 .

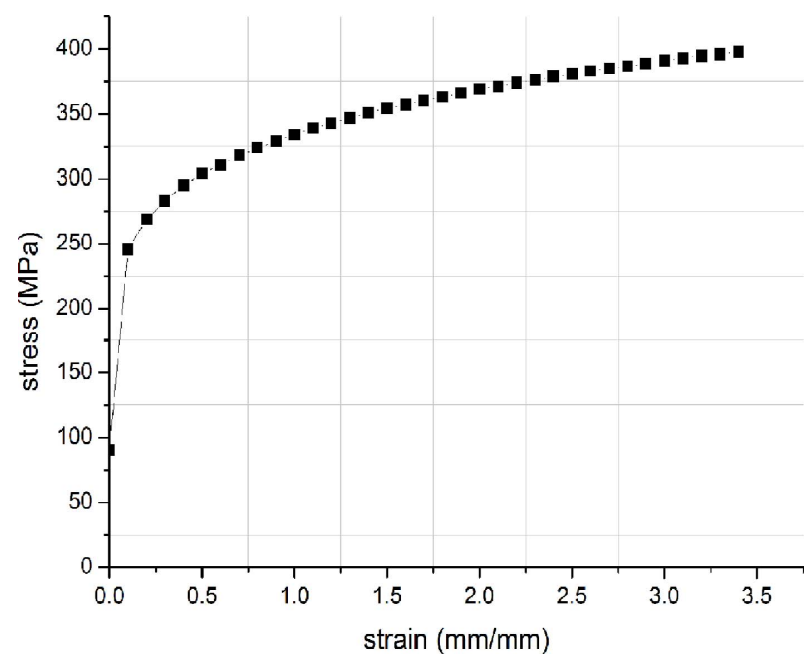

Figure 5. Experimental tensile stress- strain curve for aluminum blank sheet
Von Mises yield criterion coupled with isotropic work hardening assumption was also applied. The behavior of the nonlinear hyper-elastic and incompressible rubber-like material was again described by Mooney-Rivlin model. HD70 was used as a material of a rubber pad, with the values of $\mathrm{C} 10$ and $\mathrm{C} 01$ equal to $0.736 \mathrm{MPa}$ and $0.184 \mathrm{MPa}$ respectively.

The frictional behavior between the rubber pad and the blank, as well as the die and the blank, were assumed to follow Coulombs model. The friction coefficient at the former and later contact pair were considered to be 0.2 and 0.1 respectively.

CONTA171 andTARGE169 have been created at interface contacts. CONTA171 is used to represent contact and sliding between 2-D "target" surfaces TARGE169 and a deformable surface, defined by this element. The element is applicable to 2-D structural and coupled field contact analyses. TARGE169 is used to represent various 2-D "target" surfaces for the associated contact elements CONTA171.The target has been presented on the upper surfaces of blank (interface between blank and rubber) and die. On the other hand, the contact has been presented on lower surfaces of blank and rubber.

As it is already mentioned, the container was not modeled in order to fix the rubber pad correctly .The frictionless support was applied on the side surfaces of the rubber. In order to simulate the forming load on the blank the displacement was applied on top surface of the rubber. Remote displacement with zero in all direction was applied on the lower surface of the die, Figure3. However, in this study deformable materials have been modeled with plane 183. Plane 183 has quadratic displacement, plasticity, hyperelasticity, creep, stress stiffening, large deflection and large strain capability. Plane 183 has mixed formulation capability and can be used to calculate deformation of nearly incompressible, Elastoplastic material and fully incompressible hyperelastic material. It should be mentioned that the number of nods and elements are 200, 4450 and 200 nodes, where the elements are 102, 4220 and 172 which employed for blank, rubber pad and die respectively

\section{RESULTS AND DISCUSION}

As mentioned above, the forming force was presented as displacement applied on the upper edge of the rubber-pad (Figure 3). Figure 6 illustrates the step-bystep forming process using the rubber-pad. It is clear that the process can be divided into three stages (or steps). The first stage is the flexible die (rubber-pad) self-deformation; the second starts with the blank deformation (under the pressure of a rubber-pad when it reaches the bottom of a rigid die); and, finally, during third stage the blank fills the die cavities until they are completely filled.

Figure 7 shows the maximum value of the forming force of the rib with lightening hole, and it was $6735 \mathrm{~N}$. It can be seen that the magnitude of forming force increases as the forming steps increase, that is, as more bending regions have to be obtained (Figure 6 and Figure 7). 


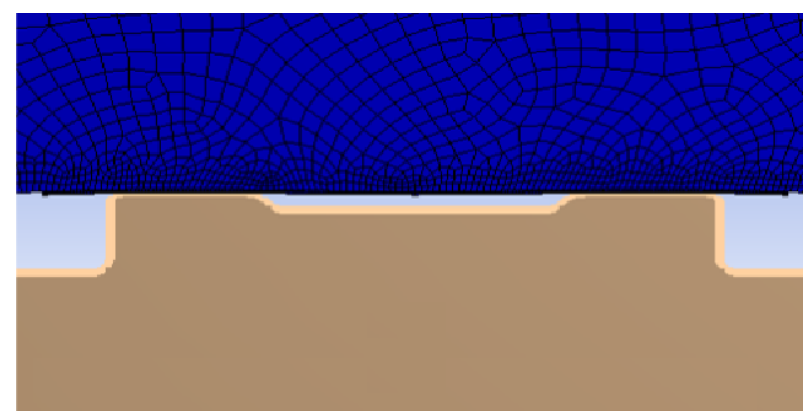

(a)

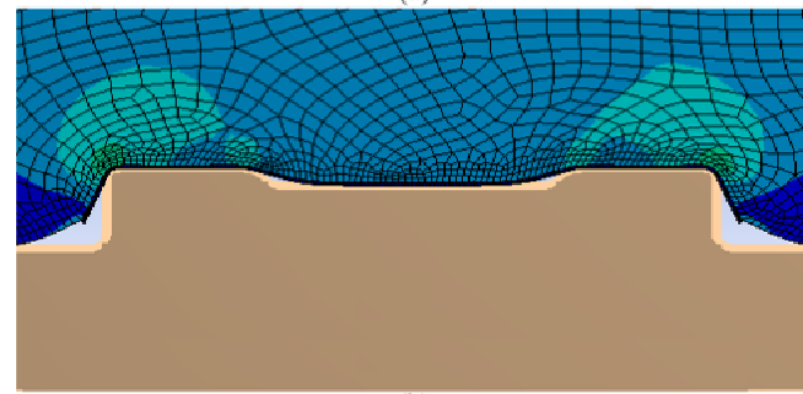

(b)

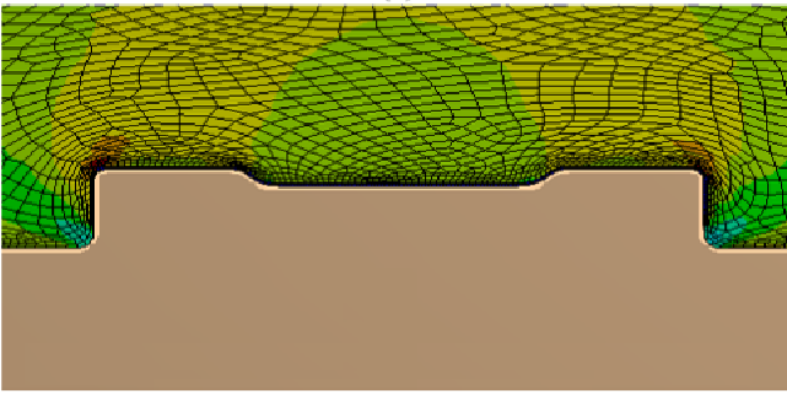

(c)

Figure 6. The three stages of supporting rib forming using rubber pad forming process

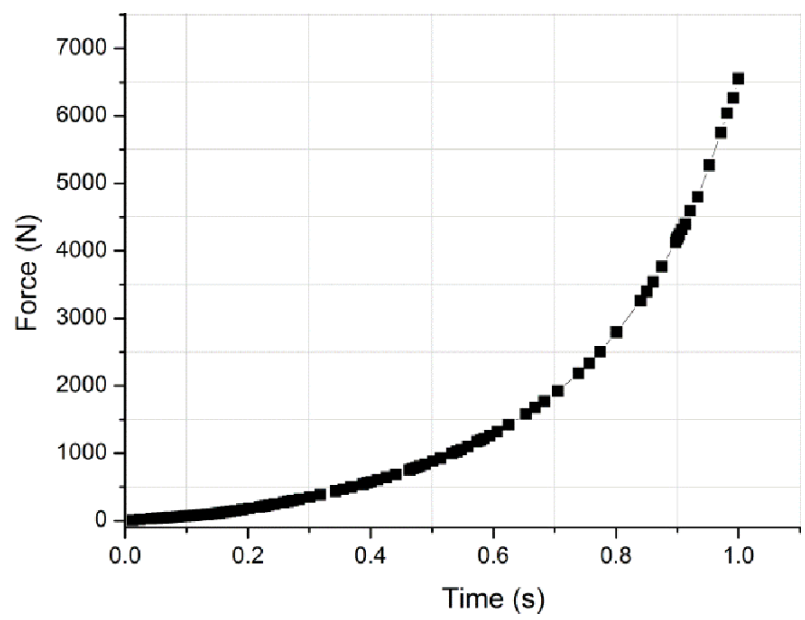

Figure 7. Forming forces for FE model of rib with lighten hole

As seen in Figure 7, the FE simulation of the forming process for rib with the lightening hole goes through three stages/steps (corresponding to the forming process), During the first step - self-forming of the rubber - rubber deforms elastically and offers a counter pressure, so the forming load is very small (Figure 6 (a) and Figure 7). Time needed for this step is short $(35 \%$ of total simulation time). After $35 \%$ of simulation time, the second step starts and forming load increases slightly to produce outer bending. During the last step, after approximately $65 \%$ of simulation time, the blank starts to fill the cavity of the rigid die and forming force increases sharply (Figure 6 (c) and Figure 7).

During the forming process, thinning and thickening phenomena can occur. However, if the maximum thickness reduction reaches a critical value, the part will be cracked. This phenomenon should be avoided in real production. According to Sala [7], Takuda [5], and Benisa et. all [16], the acceptable value of plastic strain for $2024-\mathrm{T} 3$ aluminum is $0.186 \mathrm{~mm} / \mathrm{mm}$ and this value was used as a boundary in FE simulations. This means when the value of plastic strain in simulation reached $0.186 \mathrm{~mm} / \mathrm{mm}$ the model was considered unacceptable. Generally, some parameters have higher influence on the value of plastic strain during the rubber pad forming process (tool geometry, hardness of the rubber, used lubricants), and here tool geometry parameters (RI, RII, RIII and H shown in Figure 2(b)) have been studied.

In order to study the effect of the values of these parameters on the rubber pad forming process, RI, RII, RIII and $H$ have been varied. Firstly, the values of RI, RII and RIII were fixed ( $2 \mathrm{~mm}$ in the first case and $3 \mathrm{~mm}$ in the second), while the fourth parameter $\mathrm{H}$ has been varied. The same procedure was repeated with other combinations of parameters ( 3 values were fixed, the fourth was changeable) in order to analyze the effect of each of them on strain concentration and to find combination which will minimize plastic strain. On the basis of obtained results, more FE models of tools (with different values of geometry parameters) have been developed and analyzed. These simulations showed that the values of stress and strain strongly depend on the tool rib geometry (RI, RII, RIII and H).

Different FE models based on different tool dimensions for both cases (fixed values $2 \mathrm{~mm} \& 3 \mathrm{~mm}$ ) were used in simulations. The geometry parameters that were not fixed were varied from $1 \mathrm{~mm}$ to $5 \mathrm{~mm}$. Figure 8 illustrates the relationships between the plastic strain and the geometry parameters for each model in case one and case two.

As it can be seen in Figure 8, plastic strain strongly depends on the geometry parameters RI, RII, RIII and H and these dependencies may be expressed in mathematical terms. It is also clear that increasing the values of RI, RII and RIII or decreasing the value of $\mathrm{H}$ (while other parameters are fixed), the plastic strain decreases. At the same time, the capability of forming the blank increases, too. However, when RII $\geq 2, \mathrm{RI} \geq 2$ and $\mathrm{H}<\mathrm{RII}$, for example, the plastic strain is less than $0.186 \mathrm{~mm} / \mathrm{mm}$.

On the other hand, when $\mathrm{R}_{\mathrm{I}}$ equals $1 \mathrm{~mm}$ and 1.5 $\mathrm{mm}$, respectively, the plastic strain is greater than acceptable plastic strain $0.186 \mathrm{~mm} / \mathrm{mm}$ (in both cases, one and two). Magnitudes of the plastic strain in case one is $0.219 \mathrm{~mm} / \mathrm{mm}$ (when $R_{\mathrm{I}}=1 \mathrm{~mm}$, Figure 9) and $0.211 \mathrm{~mm} / \mathrm{mm}$ (when $R_{I}=1.5 \mathrm{~mm}$, Figure 10), while magnitudes of the plastic strain in case two is 0.218 $\mathrm{mm} / \mathrm{mm}$ (when $R_{\mathrm{I}}=1 \mathrm{~mm}$, Figure 9) and $0.167 \mathrm{~mm} / \mathrm{mm}$ (when $\mathrm{R}_{\mathrm{I}}=1.5 \mathrm{~mm}$, Figure 10). Figure 9 and Figure 10 show that stress concentration appears in $R_{I}$ region in both cases. However, if $\mathrm{H}$ is greater than $\mathrm{R}_{\mathrm{II}}(\mathrm{H}=4.5 \mathrm{~mm}$, Figure 11), the maximum plastic strain is $0.438 \mathrm{~mm} / \mathrm{mm}$ in the first case and $0.244 \mathrm{~mm} / \mathrm{mm}$ in the second case (which is greater than $0.186 \mathrm{~mm} / \mathrm{mm}$ ) and stress concentration takes place at $R_{I I}$ region. But, when $H$ is 
less than $R_{I I}$ the value of plastic strain is always less than $0.186 \mathrm{~mm} / \mathrm{mm}$ (Figure 14). The plastic stain is less than $0.186 \mathrm{~mm} / \mathrm{mm}$ when $\mathrm{R}_{\mathrm{I}}>2 \mathrm{~mm}$, and the similar can be said about radius $R_{\text {II }}$, which must be greater than $2 \mathrm{~mm}$ (as shown in Figures 12 and 13).
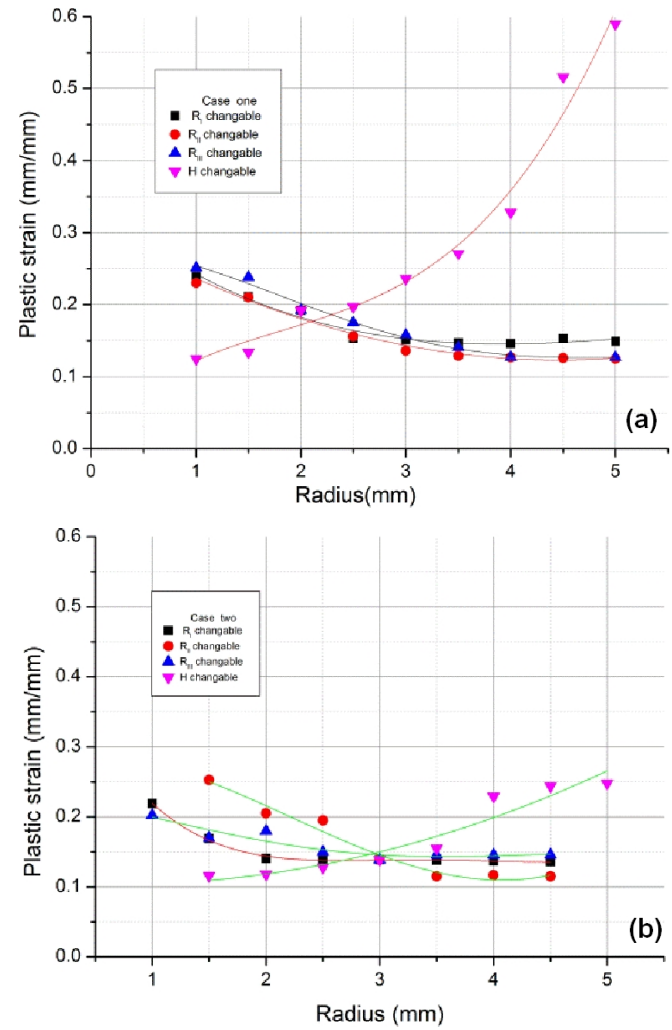

Figure 8. Influence of geometry parameters on plastic strain during rubber pad forming process: a) case one, b) case two

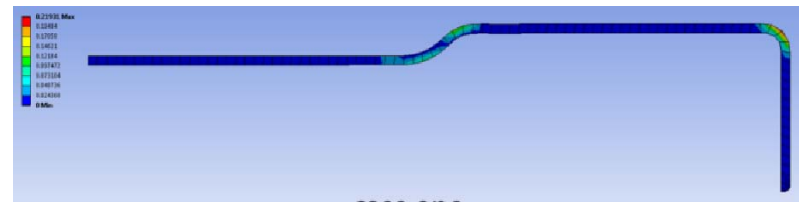

case one

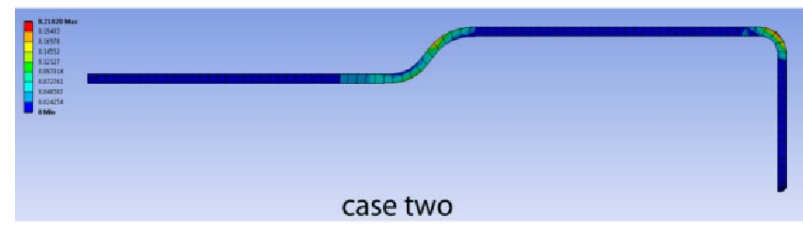

Figure 9. $R_{1}=1 \mathrm{~mm}$ a) first case $\left(R_{\mathrm{Il}}, R_{\mathrm{III}}\right.$, and $\mathrm{H}$ equal $2 \mathrm{~mm}$ )

b) second case $\left(R_{\| l}, R_{\| l l}\right.$, and $H$ equal $3 \mathrm{~mm}$ )
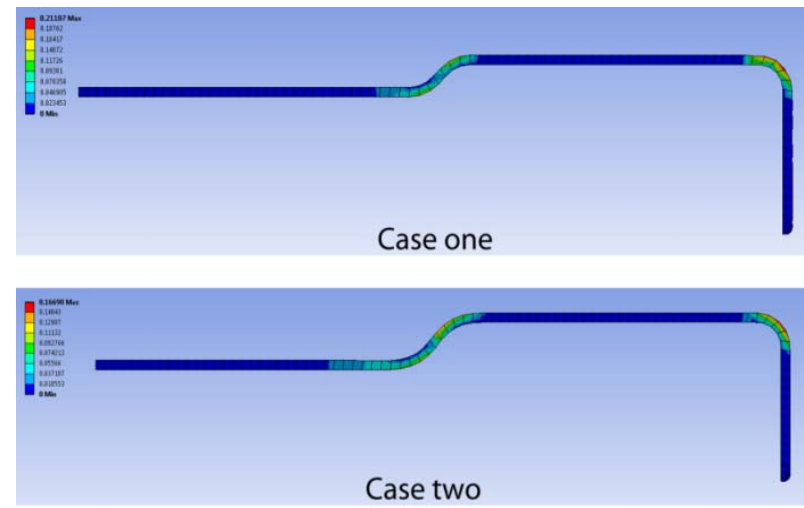

Figure 10. $R_{l}=1.5 \mathrm{~mm}$ a) first case $\left(R_{11}, R_{\mid l l}\right.$, and $H$ equal $2 \mathrm{~mm})$ b) second case $\left(R_{\| l}, R_{I I I}\right.$, and $H$ equal $\left.3 \mathrm{~mm}\right)$
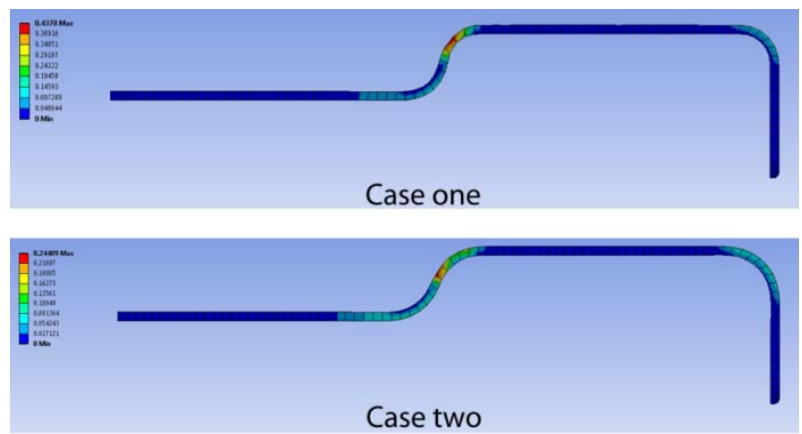

Figure 11. $\mathrm{H}=4.5 \mathrm{~mm}$ a) first case $\left(R_{\mathrm{l}}, R_{\|}\right.$and $R_{\text {III }}$ equal 2 $\mathrm{mm}$ ) b) second case $\left(R_{l}, R_{\| I}\right.$ and $R_{\mid I I}$ equal $3 \mathrm{~mm}$ )

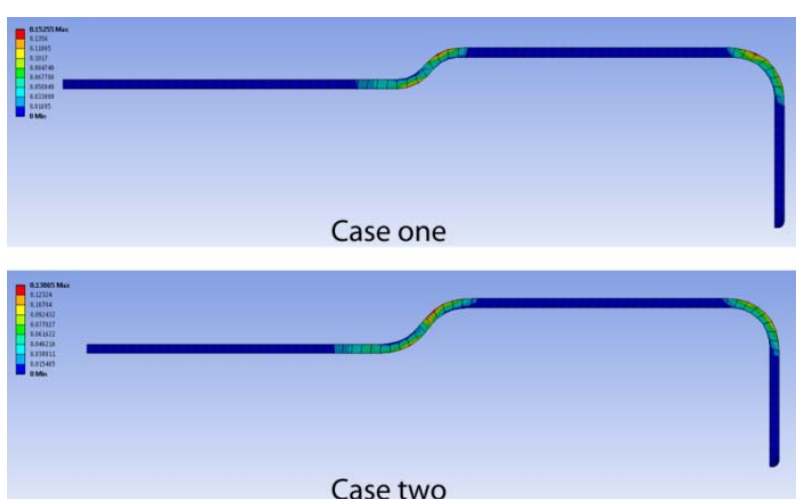

Figure 12. $R_{l}=2.5 \mathrm{~mm}$ a) first case $\left(R_{\mid l}, R_{\mid I I}\right.$ and $H$ equal $2 \mathrm{~mm}$ ) b) second case $\left(R_{I I}, R_{\mid I I}\right.$ and $H$ equal $3 \mathrm{~mm}$ )

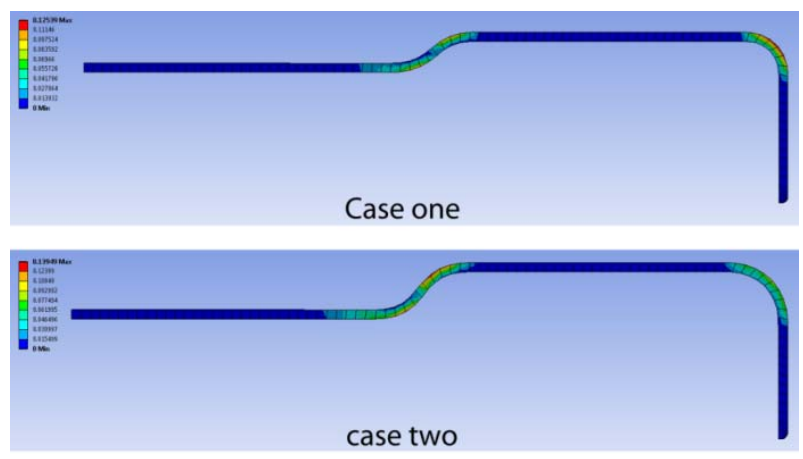

Figure $13 R_{\text {II }}=3 \mathrm{~mm}$ a) first case $\left(R_{1}, R_{\text {III, }}\right.$ and $\mathrm{H}$ equal $2 \mathrm{~mm}$ ) b) second case $\left(R_{l}, R_{I I I}\right.$, and $H$ equal $3 \mathrm{~mm}$ )
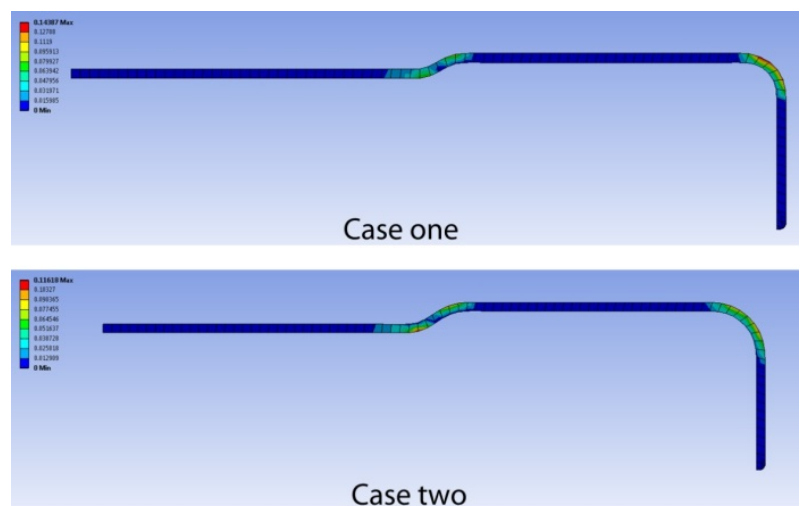

Figure 14. $\mathrm{H}=1.5 \mathrm{~mm}$ a) first case $\left(R_{l}, R_{\| l}\right.$, and $R_{|l|}$ equal 2 $\mathrm{mm}$ ) b) second case ( $R_{l}, R_{\| l}$, and $R_{I I I}$ equal $3 \mathrm{~mm}$ )

Simulations showed that the values of RIII in all models and both cases should be greater than or equal to RII in order to make an easy forming and to avoid uncompleted cavity tool forming (Figure 15). In Figure 15 it is obvious that when RIII $=1.5 \mathrm{~mm}$, and RII is 2 
$\mathrm{mm}$ (first case) and $3 \mathrm{~mm}$ (second case), cavity of the tool is not completely filled (there is a gap between sheet and tool surface). When RIII $=3.5 \mathrm{~mm}$ and $\mathrm{RIII}=4.5 \mathrm{~mm}$ (which is greater than value of RII in both cases) the cavity is completely filled and the value of plastic strain is within acceptable range (Figure 15).

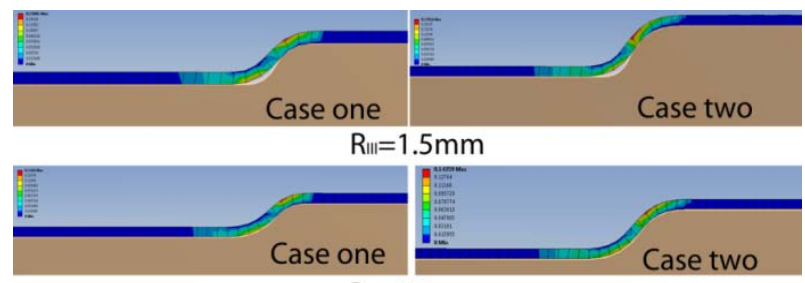

$\mathrm{R}_{\| I}=3.5 \mathrm{~mm}$

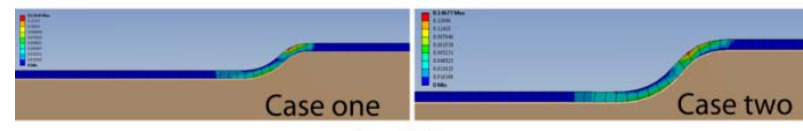

$\mathrm{R}_{\Perp 1}=4.5 \mathrm{~mm}$

Figure 15. The influence of $R_{|I|}$ on the filling the cavity of the tool rib a) case one $\left(R_{1}, R_{||}\right.$and $R_{\mid I}$ equal $2 \mathrm{~mm}$ ) b) case two $\left(R_{1}, R_{\| \mid}\right.$and $R_{\| I}$ equal $\left.3 \mathrm{~mm}\right)$

Furthermore, even if we select parameters (RI, RII, RIII and $\mathrm{H}$ ) randomly, we come to the same conclusions as previously described. For example, in Figure 16 (a) the plastic strain value is $0.212 \mathrm{~mm} / \mathrm{mm}$ and it is higher than acceptable plastic strain $(0.186 \mathrm{~mm} / \mathrm{mm})$. This high value of plastic strain is because $\mathrm{H}=4 \mathrm{~mm}$ which is greater than RII $(3 \mathrm{~mm})$, furthermore the value of RI is equal to $1.5 \mathrm{~mm}$ and less than $2 \mathrm{~mm}$. However, the tool cavity is completely filled with sheet when $\mathrm{RII}=\mathrm{RIII}=3$ $\mathrm{mm}$. When the value of RI is equal to $1 \mathrm{~mm}$ and the other parameters (RII, RIII and $\mathrm{H}$ ) are equal to $3 \mathrm{~mm}$, the plastic strain value is $0.218 \mathrm{~mm} / \mathrm{mm}$ and it is concentrated at RI region, but the tool cavity is completely filled because RIII is equal to $\mathrm{RII}=3 \mathrm{~mm}$ (Figure 16(b)). The plastic strain is equal to 0.129 $\mathrm{mm} / \mathrm{mm}$ when the value of RI is equal to $2 \mathrm{~mm}$ and the value of $\mathrm{H}$ is equal to $3 \mathrm{~mm}$, which is less than RII $(4 \mathrm{~mm})$. But, the tool cavity is not filled because RIII is equal to $2 \mathrm{~mm}$ and less than RII (Figure $16(\mathrm{c})$ ).

When $\mathrm{RI}=1.5 \mathrm{~mm}, \mathrm{RII}=2 \mathrm{~mm}$ and $\mathrm{RIII}=\mathrm{H}=3 \mathrm{~mm}$, the plastic strain value is $0.217 \mathrm{~mm} / \mathrm{mm}$ and the tool cavity is completely filled ( $\mathrm{RI}$ is less than $2 \mathrm{~mm}$ and $\mathrm{H}$ and RIII greater than RII, Figure 16(d)). The tool cavity is completely filled with low plastic strain value $(0.142$ $\mathrm{mm} / \mathrm{mm}$ ) in case when RI is equal to $2 \mathrm{~mm}$ and $\mathrm{RII}=\mathrm{RIII}=\mathrm{H}=3 \mathrm{~mm}$ (Figure 16 (e)).

The same tool cavity situation happens as in previous when $\mathrm{RI}=2 \mathrm{~mm}, \mathrm{RII}=\mathrm{RII}=3 \mathrm{~mm}$ and $\mathrm{H}$ is equal to $2 \mathrm{~mm}$ (which less than RII) and the plastic strain is $0.118 \mathrm{~mm} / \mathrm{mm}$ (Figure 16(f)). On the other hand, when $\mathrm{H}$ is equal to $3 \mathrm{~mm}$ and $\mathrm{RI}=\mathrm{RII}=\mathrm{RIII}=2 \mathrm{~mm}$ (that is $\mathrm{H}>\mathrm{RII}$ and $\mathrm{RIII}<\mathrm{RII}$ ), the value of plastic strain is 0.198 $\mathrm{mm} / \mathrm{mm}$ and is higher than $0.186 \mathrm{~mm} / \mathrm{mm}$ and the tool cavity is not completely filled (Figure16 $(\mathrm{g})$ ). The figure 16 (h) shows the sheet complely filling the tool cavity with low value of plastic strain $(0.129 \mathrm{~mm} / \mathrm{mm})$. As it can be seen this happens when RIII $=3 \mathrm{~mm}$ and RII $=4 \mathrm{~mm}$, while $\mathrm{H}=3 \mathrm{~mm}$ is less than RII and RI is equal to $2 \mathrm{~mm}$.

Figures $16(\mathrm{j})$ and $16(\mathrm{k})$ show that when the first three geometry parameters (RI, RII, RIII) are equal to 2 $\mathrm{mm}, 4 \mathrm{~mm}$ and $5 \mathrm{~mm}$ respectively, and $\mathrm{H}$ is less than or equal to RII ( $4 \mathrm{~mm}$ in Figure $16(\mathrm{j})$ and $3 \mathrm{~mm}$ in Figure $16(\mathrm{k}))$, the plastic strain is less than $0.186 \mathrm{~mm} / \mathrm{mm}$ $(0.175 \mathrm{~mm} / \mathrm{mm}$ in Figure 16 (j) and $0.134 \mathrm{~mm} / \mathrm{mm}$ in Figure $16(\mathrm{k})$ ). In case when $\mathrm{H}=3 \mathrm{~mm}$ and is equal to RIII (which is less than RII $=4 \mathrm{~mm}$, Figure $16(\mathrm{~h})$ ), while RI equal to $2 \mathrm{~mm}$, the tool cavity is completely filled with sheet metal, and the value of plastic strain is low $(0.129 \mathrm{~mm} / \mathrm{mm})$.
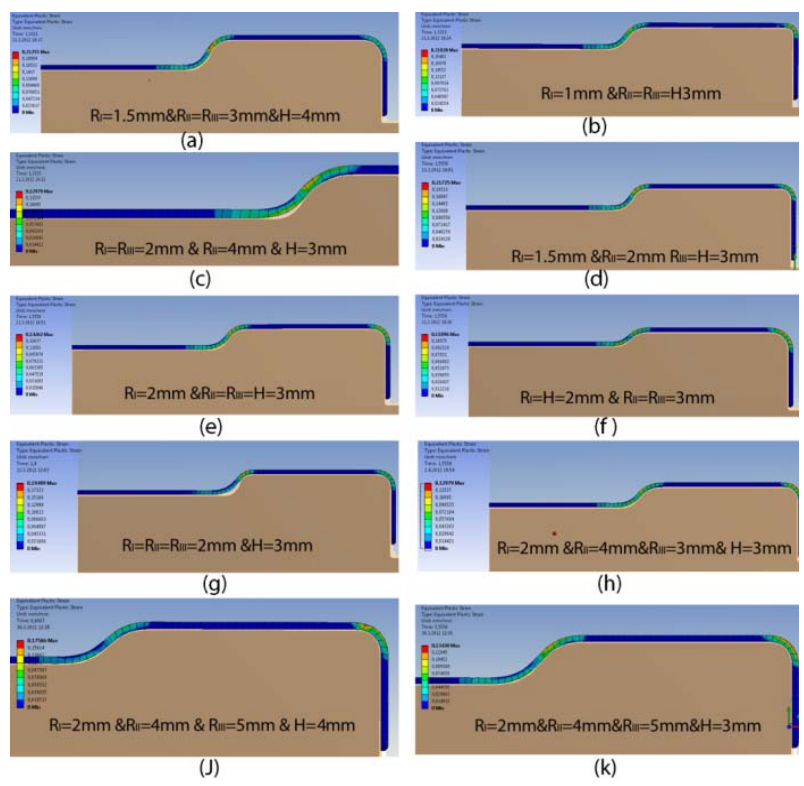

Figure 16 More randomly selected geometry parameters

\section{CONCLUSION}

In this study two different cases were analyzed using FE simulations and several different FE models of ribs' tools have been developed for the purpose of investigating the geometry of tool used in the rubber pad forming process. These models were analyzed in details numerically and the most important conclusions of this study could be:

- The values of $\mathrm{R}_{\mathrm{I}}$ and $\mathrm{R}_{\mathrm{II}}$ should be grater than or equal to $2 \mathrm{~mm}$ in order to avoid stress concentration in their regions. However, the plastic strain will not reach unacceptable plastic stain.

- To avoid thinning phenomenon and to make an easy forming with complete rib tool cavity filling, the value of $H$ should be less than $R_{I I}$ and the value of $\mathrm{R}_{\text {III }}$ should be greater than or equal to $\mathrm{R}_{\mathrm{II}}$.

To get plastic strain in the blank less than 0.186 $\mathrm{mm} / \mathrm{mm}$ and completely fill the cavity of the tool, the values of $\mathrm{R}_{\mathrm{II}} \& \mathrm{R}_{\mathrm{III}}$ should be increased with decreasing the value of $H$. On the other hand, it is known that increase of the bending radius may cause increase in the spring back phenomenon, which is not preferable. Therefore, to get an acceptable tool design we have to make a kind of compromise of the values of these parameters. This is why the connection between the values of $R_{I}$ and $R_{I I}$ and spring back phenomenon will be analyzed in next work using FE method. As we saw in presented results of simulations, the influence of $R_{\text {III }}$ and $\mathrm{H}$ on filling tool cavity is significant, but $\mathrm{R}_{\mathrm{III}}$ and $\mathrm{H}$ are not influencing the spring back, while the influence of $R_{I}$ and $R_{I I}$ on both phenomena is very important. 


\section{REFERENCES}

[1] ASM Handbook Vol. 14B Metal Working: Sheet Forming, 2006.

[2] Thiruvarudchelvan, S.: Elastomers in Metal Forming, Journal of Material Processing, Vol. 39, pp. 55-82, 1993.

[3] Del Prete, A., Panadia, G., and Manisi, B.: Computer Aided Modelling Of Rubber Forming Process, Key Engineering Material Vol. 473, pp. 637-644, 2011

[4] Dirikolu, H.M. and Akdemir, E.: Computer Aided Modelling of Flexible Forming Process, Material Processing Technology Vol. 148 pp. 376-381, 2004.

[5] Takuda, H. and Hatta, N.: Numerical Analysis of the Formability of Aluminum 2024 Alloy Sheet and Its Laminates with Steel Sheets, Metallurgical and material transaction A, Vol. 29A, pp. 2829-2834, 1998.

[6] Ramezani, M., Ripin, Z.M. and Ahmad, R.: Sheet metal forming with the aid flexible punch, numerical approach and experimental validation, CIRP Journal of Manufacturing Science and Technology, Vol. 3. No. 3, pp. 196-203, 2010.

[7] Sala, G.: A Numerical and Experimental Approach to Optimize Sheet Stamping Technologies: Part II Aluminium Alloys Rubber-Forming, Materials and Design, Vol. 22 pp.299-315, 2001.

[8] Thiruvarudchelvan, S.: The Potential Role Of Flexible Tools in Metal Forming. Material Processing Technology Vol. 122 pp. 293-300, 2002.

[9] David J.B. and Battikha, E.: Optimization of Aluminium Sheet Forming Using a Flexible Die, Material Processing Technology Vol. 55, pp. 218223, 1995.

[10]Liu, Y., Hua L., Lan. J. and Wei X.: Studies of the Deformation Styles of the Rubber-Pad Forming Process Used For Manufacturing Metallic Bipolar Plates, Journal of Power Sources Vol. 195, pp. 8177-8184, 2010.

[11] Quadrini, F., Santo L. and Squeo, E.A.: Flexible Forming of Thin Aluminum Alloy Sheets, International Journal of Modern Manufacturing Technologies, Vol. II, No. 1, pp. 79-84, 2010.

[12] Ramezani, M., Ripin, Z.M. and Ahmad, R.: Computer Aided Modelling of Friction in Rubber Pad Forming Process, Journal of Material Processing Technology Vol. 209, pp. 4925-4934, 2009.
[13]Lee, J.W., Kwon, H.C., Rhee. M.H. and Im, Y.T.: Determination of Forming Limit of a Structural Aluminum Tube in Rubber Pad Bending, Material Processing Technology, Vol. 140, pp. 487-493, 2003.

[14] Peng, L., Hu, P., Lai, X., Mei, D. and Ni, J.: Investigation of Micro/Meso Sheet Soft Stamping Process-Simulation and Experiments, Material And Design, Vol. 30, pp. 783-790, 2003.

[15] Liu, Y. and Hua, L.: Fabrication of Metallic Bipolar Plate for Proton Exchange Membrane Fuel Cells By Rubber Pad Forming, Journal of Power Source Vol. 195, pp. 3529-3535, 2010.

[16] Benisa, M., Babic, B., Grbovic, A. and Stefanovic, Z.: Computer-Aided Modeling of the Rubber-Pad Forming Process, Materials and Technology Vol. 46, No. 5, pp. 503-510, 2012.

\section{НУМЕРИЧКА СИМУЛАЦИЈА КАО АЛАТ ЗА ОПТИМИЗАЦИЈУ ГЕОМЕТРИЈЕ АЛАТА ЗА ПРОЦЕСЕ ОБРАДЕ ЛИМА У АЛАТИМА СА ГУМЕНИМ ЈЕЗГРОМ}

\author{
Muamar Benisa, Бојан Бабић, \\ Александар Грбовић, Зоран Стефановић
}

При производњи новог дела може се применити приступ пробних покушаја у циљу добијања дела без дефеката, а то у великој мери зависи од искуства радника. У овој фази искуство пројектанта и произвођача треба да пружи важну подршку за смањење броја покушаја и самим тим допринесе минимизацији времена одзива и трошкова уз максимизацију уједначености производа. Обрада лима у алатима са гуменим језгром значајно унапређује формабилност припремка због тога што су контактне површине између крутог дела алата и дела алата са гуменим језгром флексибилне. Овај метод омогућава израду делова од лима са комплексним контурама уз релативно мале трошкове због тога што је потребан само један део алата од чврстог материјала. У авио индустрији производе се делови од лима у малим количинама тако да се не исплате веће инвестиције у алате и пројектовање процеса. Из ових разлога неопходна је примена симулација технолошког процеса методом коначних елемената током концептуалног пројектовања [1]. 